\title{
MicroRNA expression profiling during the life cycle of the silkworm (Bombyx mori)
}

Shiping Liu', Liang Zhang ${ }^{2}$, Qibin Li, ${ }^{3,4}$, Ping Zhao', Jun Duan ${ }^{5}$ Daojun Cheng ${ }^{1}$, Zhonghuai Xiang ${ }^{1}$ and Qingyou Xia ${ }^{1,5^{*}}$

\section{Abstract}

Retraction article

\section{Retraction}

After publication of article [1], we became aware of the fact that Figures one C (let-7a and let-7a\#), four B (bmolet-7a and bmo-let-7a\#) and five B (let-7a and let-7a\#) were duplicated from another published article [2]. In light of these problems, the authors in consultation with the journal's Editors, have decided to retract article [1] from BMC Genomics. The authors are currently preparing a new manuscript clarifying the role of let-7a during the life cycle of the silkworm.

\footnotetext{
Author details

${ }^{1}$ The Key Sericultural Laboratory of Agricultural Ministry, College of Biotechnology, Southwest University, Chongqing 400715, PR China. ${ }^{2}$ National Engineering Center for Beijing Biochip Technology, Life Science Parkway, Changping District, Beijing 102206, PR China. ${ }^{3}$ Beijing Genomics Institute at Shenzhen, Shenzhen 518083, PR China. ${ }^{4}$ Beijing Institute of Genomics, Chinese Academy of Sciences, Beijing 100000, PR China. ${ }^{5}$ Institute of Agricultural and Life Sciences, Chongqing University, Chongqing, 400030, PR China.
}

Received: 20 April 2011 Accepted: 2 June 2011 Published: 2 June 2011

\section{References}

1. Liu S, Zhang L, Li Q, Zhao P, Duan J, Cheng D, Xiang Z, Xia Q, MicroRNA: expression profiling during the life cycle of the silkworm (Bombyx mori). BMC Genomics 2009, 10:455.

2. Liu S, Xia Q, Zhao P, Cheng T, Hong K, Xiang Z: Characterization and expression patterns of let-7 microRNA in the silkworm (Bombyx mori). BMC Developmental Biology 2007, 7:88.

doi:10.1186/1471-2164-12-284

Cite this article as: Liu et al:: MicroRNA expression profiling during the life cycle of the silkworm (Bombyx mori). BMC Genomics 2011 12:284.

\footnotetext{
* Correspondence: xiaqy@swu.edu.cn

${ }^{1}$ The Key Sericultural Laboratory of Agricultural Ministry, College of Biotechnology, Southwest University, Chongqing 400715, PR China Full list of author information is available at the end of the article
}

Submit your next manuscript to BioMed Central and take full advantage of:

- Convenient online submission

- Thorough peer review

- No space constraints or color figure charges

- Immediate publication on acceptance

- Inclusion in PubMed, CAS, Scopus and Google Scholar

- Research which is freely available for redistribution

Submit your manuscript at www.biomedcentral.com/submit

\section{() Biomed Central}

